\title{
Thompson, Lukács e o conceito de experiência - um diálogo mais que necessário
}

\author{
Giovanni Alves* \\ Renan Araújo**
}

\begin{abstract}
Resumo: O objetivo deste ensaio é fazer uma aproximação entre E. P. Thompson e Georg Lukács, buscando resgatar os fundamentos ontológicos do conceito de "experiência", tal como utilizado por Thompson. Num primeiro momento, apresentaremos a categoria de experiência em Thompson e depois a categoria de trabalho e a ontologia do ser social, de acordo com Lukács. Aproximar as análises históricas concretas desenvolvidas por E. P. Thompson da razão dialético-materialista pressuposta na ontologia do ser social de Georg Lukács é uma contribuição para a superação da miséria da razão; só assim é possível alcançarmos a necessária compreensão dialética da categoria de experiência que, enquanto práxis social, tem como modelo a categoria trabalho.
\end{abstract}

Palavras-chave: Experiência — Trabalho — Ontologia do ser social

\begin{abstract}
The objective of this essay is to make a connection between E. P. Thompson and Georg Lukács seeking rescue the ontological foundations of the concept of "experience", as used by Thompson. At first, we present the category of experience in Thompson and then, category of work and the ontology of social being, according to Lukács. Approximate the concrete historical analysis developed by E. $\mathrm{P}$. Thompson of reason dialectical-materialist presupposed in the ontology of social being of Georg Lukács is a contribution to overcoming the poverty of reason, just so you can achieve the necessary dialectical understanding of the category of experience that while social praxis is modeled the work category.
\end{abstract}

Keywords: Experience — Work — Ontology of social being

* Doutor em Ciências Sociais pela Unicamp, livre-docente em Sociologia e professor da Unesp, campus de Marília. É pesquisador do CNPq, com bolsa-produtividade em pesquisa, e coordenador-geral da Rede de Estudos do Trabalho (RET), do Projeto Tela Crítica (www.projetocinetrabalho.org) e do projeto CineTrabalho (www.projetocinetrabalho.org). É um dos líderes do Grupo de Pesquisa CNPq “Estudos da Globalização". É autor de vários livros e artigos sobre o tema trabalho e sociabilidade, entre os quais $O$ novo (e precário) mundo do trabalho: reestruturação produtiva e crise do sindicalismo (Boitempo Editorial, 2000), Trabalho e subjetividade: o espírito do toyotismo na era do capitalismo manipulatório (Boitempo Editorial, 2011) e Dimensões da Precarização do Trabalho (Editora Praxis, 2013).

** Doutor em Sociologia pela Unesp/Araraquara. Professor vinculado ao Programa de Mestrado Interdisciplinar em Formação Docente da Universidade Estadual do Paraná - Unespar/Paranavaí e ao Programa Interdisciplinar Sociedade e Desenvolvimento da Universidade Estadual do Paraná — Unespar/Campo Mourão. Membro da Comissão Executiva da Rede de Estudos do Trabalho - RET. Líder do grupo de pesquisa CNPq “Economia do Trabalho, Educação e Desenvolvimento Regional”. Autor do livro O novo perfil metalúrgico do ABC (Editora Fecilcam, Campo Mourão, 2012). 
O objetivo deste ensaio é fazer uma aproximação entre E. P. Thompson (1924-1993) e Georg Lukács (1885-1971), buscando resgatar os fundamentos ontológicos do conceito de "experiência", tal como utilizado pelo primeiro. Acreditamos que uma apreensão correta do conceito de experiência, na perspectiva de uma ontologia do ser social, possa contribuir efetivamente para a resolução da polêmica marxista da relação entre estrutura e sujeito ou entre base e superestrutura, que tanto mobilizou Thompson em suas controvérsias com o marxismo de vertente estruturalista.

O historiador marxista inglês E. P. Thompson criticou os vieses reducionistas e deterministas da problemática base e superestrutura. Por conta dessa crítica, ele foi apontado, por exemplo, por Ellen Meiksins Wood, como um autor que desprezava a especificidade da produção como determinação principal, dissolvendo, desse modo, a materialidade. ${ }^{1}$ A crítica de Wood parece, a nosso ver, tratar-se de mais um dos equívocos analíticos cometidos pelo pensamento estruturalista, pois é justamente em E. P. Thompson, precisamente em seus estudos "Costumes em Comum", que encontramos a afirmação de que "muitas das disputas clássicas do início da Revolução Industrial diziam respeito tanto aos costumes como aos salários e condições de trabalho". ${ }^{2}$ Mais ainda, Thompson não só reconheceu a existência da classe operária, mas também concebeu sua materialidade concreta enquanto expressão do processo histórico, cujas transformações diziam respeito diretamente à formação plena do capital produtivo materializado na grande indústria, momento mais avançado do modo de produção capitalista e parte do movimento histórico dialético de superação/conservação das formas pretéritas dos modos de produção e reprodução social da manufatura, do trabalho artesanal e doméstico.

Da mesma forma, E. P. Thompson (1998) alertou os historiadores para que eles não reduzissem a análise sobre os elementos históricos e sociais que compõem as esferas da "cultura e dos costumes" aos aspectos ultraconsensuais negadores da sua natureza contraditória à maneira dos antropólogos de sua época, qual seja: um sistema de atitudes, valores e significados compartilhados às formas simbólicas em que se acham incorporados. Em Thompson, ao contrário da visão antropológica, a cultura e os costumes devem ser analisados enquanto processo de reprodução social contraditório na medida em que estes são compostos por diferentes recursos e

há sempre uma troca entre o escrito e o oral, o dominante e o subordinado, a aldeia e a metrópole, uma arena de elementos conflitivos que sob uma pressão imperiosa, por exemplo, o nacionalismo, a consciência de classe ou a ortodoxia religiosa predominante, assume a forma de um sistema [...] o próprio termo cultura, com sua invocação confortável de um consenso, pode distrair nossa atenção das contradições sociais e culturais, das fraturas e oposições existentes dentro do conjunto. ${ }^{3}$

Justamente por isso podemos afirmar que, na perspectiva thompsoniana, existe uma base ontológica da práxis social. Portanto, o objetivo do ensaio é aproximar Thompson da reflexão ontológica do último Lukács, que salientou a categoria trabalho como modelo ontológico da práxis social. Desse modo, a solução da

1 WOOD, Ellen Meiksins. "Falling through the cracks: E. P. Thompson and the Debate on Base and Superstructure”. In: KAYE, Harvey J.; McCLELLAND, Keith. E. P. Thompson: Critical Perspectives. London: Temple, 1990.

2 THOMPSON, E. P. Costumes em Comum: Estudos sobre a cultura popular tradicional. Tradução: Rosaura Eichemberg. São Paulo: Companhia das Letras, 1998, p. 16.

3 Ibidem, p. 17. 
problemática marxista deve romper a camisa de força imposta pelo reducionismo estruturalista que permaneceu encapsulado no circuito fechado de um "radicalismo abstrato idealista".

Embora tenha contribuído para a exaustiva discussão sobre os aparelhos ideológicos e sobre a relação entre base e superestrutura, o marxismo estruturalista foi incapaz de perceber que base e superestrutura resultam das relações históricas contraditórias modernas, das relações de produção e reprodução social capitalista. Mais ainda, o proletariado - classe social que ascendeu desse contraditório processo - trazia em si as contradições apresentadas no plano material e cultural (formas de ser, viver, sentir e pensar a sua própria reprodução cotidiana), da longa trajetória moderna da qual emergiu enquanto sujeito social portador de novas possibilidades históricas, considerando que, em potência, trazia a promessa de negação do mesmo processo que assentava sua nascença.

Portanto, aproximar as análises histórico-concretas desenvolvidas por E. P. Thompson da razão dialética pressuposta na ontologia do ser social de Georg Lukács é uma contribuição para a superação da miséria da razão; só assim é possível alcançarmos a necessária compreensão dialética da categoria de experiência que, enquanto práxis social, tem como modelo a categoria trabalho.

Ao tratar da categoria trabalho, Lukács conseguiu apreendê-la primeiro como categoria fundante e fundamental do ser social e depois como modelo da práxis social capaz de articular as categorias de liberdade/necessidade e de teleologia/causalidade. Esse construto lógico (e ontológico) é a base fundamental (e fundante) da explicação dialético-materialista da relação entre estrutura e sujeito. Nossa hipótese é que a dialética da categoria trabalho é a base ontológica primordial da categoria de experiência de Thompson utilizada para a apreensão da práxis histórica.

A discussão da relação entre estrutura e sujeito tornou-se a discussão crucial no marxismo do pós-guerra. Na década de 1960, com a afluência do americanismo e do fordismo no plano do capitalismo mundial, irrompeu na França a hegemonia estruturalista que influenciou o marxismo. Entretanto, a episteme estruturalista, apropriada pela reflexão marxista com os althusserianos, deu uma resolução equivocada para a problemática da práxis humana, dissolvendo o sujeito na estrutura. Conforme salientou Coutinho (2010), o "idealismo subjetivo" caracterizado pela angústia existencialista, pensamento disseminado em meio à crise que assolou o capitalismo, culminando na segunda guerra, foi substituído mais tarde pelo "idealismo objetivo", tão logo se anunciou o período de estabilidade caracterizado pelo welfare state. À guisa desse processo é que, relacionado às importantes transformações na estrutura do sistema,

as correntes racionalistas voltam a ocupar — como já ocorrera na segunda metade do século XIX —, um papel preponderante. Sem renunciarem ao agnosticismo, alimentavam a pretensão de submeterem amplas esferas da realidade aos esquemas de sua racionalidade formalista. ${ }^{4}$

Tal qual apontou Coutinho (2010), "a miséria da razão", corporificada no arcabouço teórico do estruturalismo, contribuiu inadvertidamente para que, no limite, a partir dos anos de 1960, ocorresse no plano ideológico uma reação conservadora que ganhou força nas décadas seguintes com o ceticismo epistemológico, que caracterizou tanto o pós-estruturalismo quanto o pós-modernismo, e que

4 COUTINHO, Carlos Nelson. O Estruturalismo e a Miséria da Razão. São Paulo: Expressão Popular, 2010, p. 59. 
dissolveu o sujeito histórico. Por exemplo, Perry Anderson salientou que o estruturalismo engendrou o pós-estruturalismo, observando que a passagem de um para o outro representou o movimento final logicamente viável denominado "inversão das estruturas". Do objetivismo puramente ascético para o subjetivismo orgiástico foi um passo fácil e congruente, sem rupturas fundamentais das continuidades entre ideias e autores. Ele se interroga: "[...] se as estruturas sozinhas existem num mundo para além de todos os sujeitos, o que assegura a sua objetividade?" Desse modo, o pós-estruturalismo prosseguia com a negação do sujeito iniciada pelo estruturalismo, promovendo um campo lógico comum que levou, por exemplo, à "exorbitação da linguagem". 5

É a perspectiva ontológica pressuposta na reflexão de E. P. Thompson sobre o conceito de experiência histórica que evita reduzi-la a um culturalismo frouxo ou a um idealismo plausível, tanto quanto considerar a estrutura material apartada do condicionante humano. Quando analisada pela concepção estruturalista, as ações coletivas empreendidas pelos sujeitos sociais perdem-se em meio a dados estéreis. Por outro lado, pensar as ações sociais apenas pelo viés cultural é dissolver o sujeito humano no contexto enquanto categoria explicativa. Desse modo, a explicitação dos fundamentos ontológicos da experiência histórica em Thompson contribui para afastá-la não apenas da miséria do estruturalismo, mas dos vieses culturalistas, pós-estruturalistas e pós-modernistas.

Thompson buscou, e com sucesso, compreender na sua totalidade concreta a tessitura da história de homens e mulheres reais imersos naquilo que denominamos condição existencial de proletariedade. ${ }^{6}$ Com a categoria de experiência, ele recuperou na pesquisa histórica a mais fina articulação dialética entre liberdade e necessidade ou, ainda, teleologia e causalidade, que teve na filosofia sócio-ontológica do último Lukács a expressão mais acabada no marxismo do século XX.

Tanto o último Lukács quanto Thompson presenciaram a reação estruturalista e pós-estruturalista no debate da relação entre sujeito e estrutura (um detalhe: Lukács só presenciou a vigência estruturalista, tendo em vista que faleceu em 1971 e não acompanhou o desenvolvimento do pós-estruturalismo e do pós-modernismo). Os dois - o último Lukács e Thompson, cada um a seu modo reafirmaram a perspectiva materialista, histórica e dialética da problemática da práxis social, recusando as antinomias postas pela discussão hegemônica com o althusserianismo, com o pós-estruturalismo e com o pós-modernismo. Em última instância, a solução dialética da problemática da práxis social exigia aquilo que Lukács buscou resgatar no pensamento marxiano: a ontologia do ser social. Embora não explicite efetivamente sua perspectiva ontológica pressuposta em suas reflexões sobre a experiência histórica, a abordagem thompsoniana da experiência histórica contém uma apreensão dialético-materialista da práxis humana, como tentaremos demonstrar a seguir (mesmo assim, instigado pelo debate teórico com os althusserianos, Thompson publicou em 1978 o livro "A Miséria da Teoria ou um planetário de erros").

5 ANDERSON, Perry. A crise da crise do marxismo: introdução a um debate contemporâneo. Tradução: Denise Bottman. São Paulo: Brasiliense, 1983, p. 59.

6 ALVES, Giovanni. A condição de proletariedade: A precariedade do trabalho no capitalismo global. Bauru: Editora Práxis, 2009. 


\section{O conceito de experiência histórica em E. P. Thompson}

Ao buscar desvelar a dialética entre prática social e estrutura, agir humano e determinação, luta e condições sociais, E. P. Thompson distinguiu experiência I (experiência vivida) de experiência II (experiência percebida). O exercício teórico de Thompson visou fazer contraponto ao althusserianismo, para o qual a experiência é puramente ideológica e a classe mero depositário do processo histórico, processo esse que prescinde de sujeitos.

Muitos epistemológos e sociólogos contemporâneos, diz Thompson, quando ouvem a palavra "experiência" identificam-na imediatamente à experiência II, a experiência percebida; isto é, movem-se na direção do que Marx denominou "consciência social". Como consequência, afirmam que a "experiência II" é um meio imperfeito e falsificador, corrompido por interferências ideológicas. Entretanto, Thompson observa que as regularidades no interior do ser social, com frequência, resultam de causas materiais que ocorrem de forma independente da consciência ou da intencionalidade. Tais causas inevitavelmente dão ou devem dar origens à experiência vivida, à experiência I, mas não penetram como "reflexos" na experiência II. No entanto, a pressão dessas causas sobre a totalidade do campo da consciência não pode ser adiada, falsificada ou suprimida indefinidamente pela ideologia. Retomando argumentos expostos no seu livro "A Miséria da Teoria...", Thompson assevera:

A experiência entra sem bater à porta e anuncia mortes, crises de subsistência, guerras de trincheira, desemprego, inflação, genocídio. Pessoas estão famintas: seus sobreviventes têm novos modos de pensar em relação ao mercado. Pessoas são presas: na prisão, pensam de modos diversos sobre as leis $[. . .]^{7}$

Em “The Politics of Theory", ele nos diz:

Dentro do ser social ocorrem mudanças que dão origem a uma experiência transformada: e essa experiência é determinante, no sentido de que exerce pressão sobre a consciência social existente, propõe novas questões e oferece grande parte do material com que lidam os exercícios intelectuais mais elaborados.

E, mais adiante, observa:

A experiência I está em eterna fricção com a consciência imposta e, quando ela irrompe, nós, que lutamos com todos os intrincados vocabulários e disciplinas da experiência II, podemos experienciar alguns momentos de abertura e de oportunidade, antes que se imponha mais uma vez o molde da ideologia. ${ }^{8}$

Dessa forma, a experiência, “sem bater na porta”, constitui e nega, opõe e resiste, estabelece mediações, é espaço de prática, intervenção, obstaculizações,

7 THOMPSON, E. P. A Miséria da Teoria ou um planetário de erros: uma crítica ao pensamento de Althusser. Tradução: Waltensir Dutra. Rio de Janeiro: Zahar Editores, 1978, p. 17.

8 THOMPSON, E. P. "The Politics of theory". In: SAMUEL, Raphael (Ed.). People's history and socialist theory. London: Routledge, 1981, p. 191. (tradução nossa) 
recusa, é processo de formação de identidades de classe e, poderíamos acrescentar, de gênero, de geracional e de etnias. Processos dialeticamente articulados que, ela, a experiência, expressa de forma privilegiada.

Nesse sentido, Thompson distancia-se, por um lado, do conceito vulgar de "experiência", que estabelece sua equivalência com a empiria, mesmo porque, como sublinham Moraes e Torriglia, "a construção empiricista da experiência induz ao relativismo e à passividade e à aceitação de todo o status quo", posição que está na contramão da proposta intelectual e de vida do historiador. ${ }^{9}$ Por outro lado, Thompson distancia-se - embora este é o ponto controverso da obra thompsoniana - de uma concepção culturalista de experiência que, ao se preocupar em demasia com aspectos culturais e com a luta ativa consciente, descuida-se de categorias econômicas estruturais.

Para Thompson, a fina articulação entre a experiência l e a experiência ll é a única maneira possível de "explicar a mudança histórica com alguma racionalidade". ${ }^{10}$ As experiências históricas e suas articulações seriam inevitáveis e contínuas. Teriam a função de exercer pressão sobre a consciência social, determinando a construção de materiais humanos conscientes de seus papéis na sociedade de classes. Além disso, Thompson argumenta, ainda, que o conceito de experiência histórica serve para que os historiadores percebam que não é possível pensar determinada classe social separada da outra, ou propor graus de importância e autenticidade entre elas. Diz ele:

Em uma análise comparativa, o modelo tem apenas valor heurístico, passível de geralmente redundar em perigo dada sua tendência em direção a uma estase conceitual. Na história, nenhuma formação de classe específica é mais autêntica ou mais real que outra. As classes se definem de acordo com o modo como tal formação acontece efetivamente. ${ }^{11}$

Na verdade, o esforço teórico de Thompson era perseguir a verdadeira mediação entre cultura e não cultura, tertium datur deste processo ativo, que é, segundo ele, "o processo através do qual os seres humanos fazem sua história". Não poderíamos compreender a matéria-prima da "experiência da vida" — a ação humana — sem recorrer ao conceito de "modo de produção"; nem poderíamos compreender os sistemas articulados que "manejam", transmitem ou distorcem a ação humana, sem o conceito de "ideologia". O esforço de tertium datur de Thompson está explícito, por exemplo, na sua defesa do conceito de experiência, articulando-o ao de cultura. Para ele, experiência é exatamente o que realiza a junção entre cultura e não cultura, ficando uma metade dentro do ser social (experiência I — experiência vivida) e a outra metade no âmbito da consciência social (experiência II - experiência percebida). Desse modo, para Thompson, o conceito de experiência é um junction-concept - conceito mediador. Por isso, em sua polêmica sobre "A Miséria da Teoria...", no debate do Workshop History ${ }^{12}$, ele asseverou:

Toda teoria da cultura deve incluir o conceito da interação dialética entre cultura e algo que não é cultura. Devemos supor que a matériaprima da "experiência de vida" esteja em um dos pólos, e todos os infinitamente complexos sistemas e disciplinas humanos, articulados ou

9 MORAES, Maria Célia M.; TORRIGLIA, Patricia L. "Educação light, que palpite infeliz. Indagações sobre as propostas do MEC para a formação de professores”. Teias, Rio de Janeiro, ano 1, n. 2, p. 53, 2000.

10 THOMPSON, E. P. op. cit., 1981, p. 406.

11 THOMPSON, E. P. As peculiaridades dos ingleses e outros artigos. Campinas: Ed. da UNICAMP, 2001, p. 277.

12 THOMPSON, E. P. op. cit., 1981, p. 420. 
não, formalizados em instituições ou dispersos das maneiras menos formais que "manejam", transmitem ou distorcem esta matéria-prima, estejam no outro pólo. É sobre este processo ativo, que é, ao mesmo tempo, o processo através do qual os seres humanos fazem sua história, que venho insistindo. ${ }^{13}$

Na medida em que Thompson não elabora categorialmente uma ontologia do ser social - embora a categoria de experiência para ele tenha uma base ontológica -, ele não consegue expressar com desenvoltura, em termos lógico-dialéticos, a metodologia de Marx. Toda a discussão da relação entre estrutura e sujeito — e em última instância, base e superestrutura, por exemplo — remete ao problema crucial das "determinações", que expressa, por conseguinte, o problema da práxis social ou da ação histórica dos homens.

A longa citação do filósofo marxista húngaro István Mészáros, que apresentaremos a seguir, torna-se importante para contrastar (e não contrapor) o modo de exposição de Mészáros da problemática das "determinações", com a exposição de Thompson no resgate do caráter dialético do conceito-mediador de experiência. Diz Mészáros:

Aqui chegamos a uma questão crucial: a complexidade da metodologia dialética de Marx. Em uma concepção mecanicista, há uma linha de demarcação definida entre o "determinado" e seus "determinantes", mas não é o que ocorre no quadro de uma metodologia dialética. Nos termos dessa metodologia, embora os fundamentos econômicos da sociedade capitalista constituam os "determinantes fundamentais" do ser social de suas classes, eles são também, ao mesmo tempo, "determinantes determinados".

\section{E prossegue:}

Em outras palavras, as afirmações de Marx sobre o significado ontológico da economia só fazem sentido se formos capazes de apreender sua ideia de "interações complexas", nos mais variados campos da atividade humana. Desse modo, as várias manifestações institucionais e intelectuais da vida humana não são simplesmente "construídas sobre" uma base econômica, mas também estruturam ativamente essa base econômica, através de uma estrutura própria, imensamente intrincada e relativamente autônoma. "Determinações econômicas" não existem fora do complexo historicamente mutável de mediações específicas, incluindo as mais "espirituais". Na visão de Marx, "os deuses são, originariamente, não a causa, mas o efeito do erro do entendimento humano. Mais tarde essa relação se transforma em ação recíproca".

Como consequência, uma vez que crenças desse tipo — ou mesmo de qualquer outro - são aceitas pelo homem, elas trazem consigo repercussões múltiplas para a totalidade da vida humana, incluindo o "fato econômico" de "alocar recursos escassos" para a construção de catedrais, para a manutenção da Igreja e do clero etc. O mesmo ocorre com a consciência, em todas as suas formas e manifestações, que têm uma estrutura própria relativamente autônoma, determinando, assim, de forma recíproca, as estruturas econômicas da sociedade, ao mesmo tempo que são também determinadas pela última. "Oferta e procura", "produção e consumo" são categorias econômicas par excellence, mas

13 Apud MORAES, Maria Célia M. de; MÜLLER, Ricardo Gaspar. "A Miséria da Teoria - O Debate de History Workshop". Esboços, Florianópolis, v. 12, n.14, p. 29, 2005. 
somente na superfície. Um exame mais cuidadoso revela que nenhuma delas faz qualquer sentido, seja qual for, sem a categoria historicamente mutável das "necessidades humanas", que não pode ser explicada, de modo plausível, em termos de determinações econômicas unilaterais. ${ }^{14}$

Na verdade, ao desdobrar a experiência em experiência I e experiência II, Thompson quis salientar o caráter de "determinação determinada" da experiência histórica. Existiu um esforço categorial para expressar o caráter dialético da relação entre estrutura e sujeito e entre base e superestrutura. É claro que Thompson, como Mészáros, possui, na abordagem da problemática da experiência histórica, uma base ontológica no sentido do materialismo histórico-dialético. Entretanto, como vimos acima, é flagrante a desenvoltura dialética da colocação meszariana da problemática da práxis social que se contrasta, por exemplo, com as dificuldades expositivas, no plano lógico-categorial, da proposição thompsoniana da experiência como junction-concept (talvez o avesso à lógica dialética intrínseco à experiência intelectual inglesa mais próxima do empirismo que do racionalismo contribuiu para a dificuldade de resolução lógico-categorial da problemática dialética da experiência histórica).

\section{Thompson e a crítica do culturalismo}

Na medida em que Thompson propõe um tertium datur entre cultura e não cultura na apreensão do conceito de experiência histórica, ele se afasta decisivamente das interpretações culturalistas do termo e de sua negação de determinações materiais ou estruturais na formação da identidade dos sujeitos sociais. Em contraposição a essas interpretações, ele indica que, "na medida em que uma noção é endossada pelas evidências, temos então todo o direito de dizer que ela existe 'lá fora', na história real". ${ }^{15}$ Dessa maneira, para o historiador inglês, há referentes materiais. Portanto, o solo ontológico da experiência é a história real e não a cultura, como salientam os culturalistas, ou a linguagem como dizem os pós-estruturalistas. Se cultura e experiência são um ponto de junção, apesar do que ajuízam os adeptos da "pós-condição", a cultura não tem, para Thompson, qualquer autonomia.

E. P. Thompson é incisivo ao refutar o suposto caráter culturalista de sua obra e ao reafirmar a categoria de experiência nos termos materialistas originalmente por ele propostos. Desse modo, Thompson não aceita a acusação de Richard Johnson no debate de History Workshop, de que teria interpretado à luz da cultura a categoria marxista de consciência de classe e contribuído para fortalecer os estudos culturais com seu The Making of the English Working Class (1963). Em "The politics of theory", Thompson afirma: "Rejeito, incondicionalmente, o título de ‘culturalismo' dado à tradição historiográfica marxista da qual sou considerado representante." ${ }^{16}$ No quadro de seu materialismo histórico, o conhecimento de classe seria impossível sem a compreensão das experiências que emergem dos confrontos entre classes, em função também das diferenças entre as várias culturas, políticas, e entre religião, valores, convenções.

\footnotetext{
14 MÉSZÁROS, István. Filosofia, Ideologia e Ciência Social. Tradução: Ester Vaisman. São Paulo: Boitempo Editorial, 2008, p. 77. (grifo nosso)

15 THOMPSON, E. P. op. cit., 1978, p. 232-235.

16 THOMPSON, E. P. op. cit., 1981, p. 396.
} 
Portanto, experiência e cultura são articuladas por Thompson, constituindo ambas um ponto de junção entre estrutura e processo, entre as determinações objetivas do ser social e a possibilidade do agir e da intervenção humanos. ${ }^{17} \mathrm{Nes}$ se sentido, são "conceitos de junção" (junction-concepts) ou, adotando a sintaxe dialética de I. Mészáros, "determinações determinadas". O que significa que, para Thompson, homens e mulheres atuam e constroem suas vidas em condições determinadas e vivem essa experiência tanto no âmbito do pensamento como no do sentimento. Na cultura, afirma Thompson, os sujeitos lidam com o sentimento como normas, obrigações familiares e de parentesco e reciprocidades, como valores, ou mediante formas mais elaboradas na arte ou nas convicções religiosas. E continua:

Os valores não são apenas "pensados", nem "chamados"; são vividos e emergem no interior do mesmo vínculo com a vida material e as relações materiais em que surgem nossas idéias. São as normas, regras, expectativas etc., necessárias e aprendidas (e "aprendidas" no sentimento), no habitus de viver; e aprendidas, em primeiro lugar, na família, no trabalho e na comunidade imediata. Sem esse aprendizado a vida social não poderia ser mantida e cessaria toda produção. ${ }^{18}$

\section{Thompson e a crítica do pós-estruturalismo}

Ao mesmo tempo em que criticou o viés culturalista, Thompson criticou o viés pós-modernista presente no pensamento pós-estruturalista, que concede demasiada primazia teórica, segundo ele, à linguagem, não só por ser o veículo, mas a influência constitutiva sobre a consciência. A virada linguística do pós-estruturalismo é, segundo Thompson, o outro lado da miséria do estruturalismo no tocante à problemática do sujeito. Criticando a historiografia que adere a tal posição, diz ele:

Embora a linguagem real — por exemplo, o dialeto - tenha sido pouco
estudada, entrou na moda presumir que a plebe era em certo sentido
determinada pela sua herança lingüística, considerada, por sua vez, uma
verdadeira bricolage de idéias díspares, derivadas de muitas fontes, mas
mantidas no seu lugar pelas categorias patrícias. Os plebeus chegam
a ser vistos como prisioneiros da linguagem, compelidos, até mesmo
em seus momentos de rebeldia, a mover-se dentro dos parâmetros do
constitucionalismo, da Velha Inglaterra, da deferência devida aos líde-
res do patriciado e do patriarcado. ${ }^{19}$

Thompson observou que seus críticos capitulam "ao subjetivismo da moda e ao idealismo agora tão corrente. Essa moda parece que vai durar pelo menos uns vinte anos...". E observou: "Triste e totalmente desnecessário, porque a escolha que nos é oferecida, um positivismo grosseiro ou um idealismo 'plausível', é completamente falsa. Teoria e evidência devem estar sempre em diálogo entre si". ${ }^{20}$

Na verdade, Thompson compreendeu tardiamente o "subjetivismo da moda" ou o "idealismo plausível” representado pela agenda pós-moderna; percebeu a inversão pós-moderna e pós-estruturalista que desfoca o lugar e o papel da experiência na construção do conhecimento, dos interesses e das identidades sociais, co-

17 THOMPSON, E. P. op. cit., 1978, p. 362.

18 Ibidem, p. 367.

19 THOMPSON, E. P. op. cit., 1998, p. 10. (grifo no original)

20 THOMPSON, E. P. "Theory and evidence”. History Workshop Journal, n. 35, p. 274-275, 1993a. (grifo no original). 
locando em seu lugar, isoladamente, a linguagem ou a cultura. Müller assinala que seria inadmissível para o historiador aceitar que a experiência fosse "codificada" e aprisionada dentro de um corpus de linguagem e de textos, corpus tão dominante e onipotente que virtualmente a subsumiria. ${ }^{21}$

Da mesma forma, o papel de relevo que Thompson confere à cultura em suas análises históricas distancia-se das acepções que lhe têm sido atribuídas pelos culturalistas de toda cepa. O historiador inglês distingue-se radicalmente daqueles que pensam a pesquisa meramente como empirias compartilhadas, eivadas de relativismo e de culturalismos, ou permeadas com constructos discursivos. Como observou Moraes e Torriglia, Thompson inspira os que compreendem os fatos sociais como fatos históricos e os que, nessa perspectiva, descartam a teoria como "verdade" ou como "modelo" fictício e abraçam o desafio do conhecimento como percurso, sempre provisório e aproximado, prenhe de "silêncios e impurezas". ${ }^{22}$

\section{Experiência histórica e condição de proletariedade}

Podemos dizer que experiência vivida na acepção de Thompson é a experiência vivida da condição existencial de proletariedade. É, portanto, uma experiência de classe, ou melhor, experiência de uma individualidade pessoal de classe, em que, nesse caso, a classe remete às relações de produções nas quais os indivíduos são involuntariamente inseridos (é o que consideramos, por exemplo, como "classe" com aspas). A experiência vivida remete ao ser social (a experiência I de Thompson). Mas não existe experiência vivida que não seja também experiência percebida (a experiência II de Thompson), no sentido de consciência social com percepção e entendimento da condição existencial. É a experiência II que remete à consciência social ou ideológica. Os homens dão respostas às condições existenciais por meio da ideologia: eis o caráter positivo da ideologia, no sentido de Gramsci e Lukács, em que ideologia não se reduz à falsa consciência, mas sim significa consciência social.

Desse modo, o conceito de experiência em Thompson é visceralmente um conceito ontológico que explicita a dialética entre ser social e consciência social baseada na dialética entre liberdade e necessidade ou, ainda, na dialética entre teleologia e causalidade intrínseca à categoria trabalho. Na verdade, o conceito de experiência em Thompson como "conceito de junção" ou como "determinação determinada" desempenha um papel mediador entre a consciência social e o ser social. Dessa forma, é um instrumento categorial rico para apreendermos o que as pessoas, isto é, as individualidades pessoais de classe, estão fazendo de si mesmas frente às determinações da condição de proletariedade.

Assim, o sujeito da ação histórica são individualidades pessoais, homens e mulheres que trabalham, e que vivem sua própria história sob determinadas condições objetivas. Além disso, o conceito de experiência diz respeito a uma "experiência histórica" no interior da qual se elabora um espaço de ação no qual se constitui um sujeito de experiência que ocorre através do tempo. O que significa que o sujeito de experiência é um sujeito capaz de narrativas. Thompson observa: "É possível para as pessoas fazer de si mesmas algo diferente do que aquilo que a história fez delas.” Entretanto, os sujeitos da experiência

21 MÜLLER, Ricardo G. Razão e Utopia: Thompson e a História. Diálogos - UEM, Maringá, v.6, n.6, p. $30,2000$.

22 MORAES, M. C. M.; TORRIGLIA, P. L. op. cit. 
não aparecem como "sujeitos autônomos", "indivíduos livres”, mas como pessoas que experimentam suas situações e relações produtivas determinadas como necessidades, interesses e como antagonismos; e em seguida, "tratam" essa experiência em sua consciência e sua cultura, das mais complexas maneiras e em seguida, agem, por sua vez, sobre sua situação determinada. ${ }^{23}$

A experiência é sempre gerada na vida material sob a pressão determinante do modo de produção sobre a consciência dos indivíduos.

\section{A categoria trabalho e o resgate da perspectiva ontológica em Lukács}

A preocupação de Georg Lukács com a “Ontologia do Ser Social”, numa perspectiva histórico-materialista, está intimamente ligada à necessidade de instaurar as bases epistemológicas para o conhecimento do ser social naquilo que ele tem de "fundante" e de "estruturante", isto é, instituir as bases ontológicas do Pensamento e da Atividade humana a partir da categoria trabalho, formada por posições teleológicas que põem em funcionamento séries causais; e a consideração do Todo, na sua forma de ser, como processo histórico que se transforma.

É interessante que a preocupação do último Lukács tenha ocorrido no decorrer dos anos de 1960, um momento histórico em que o marxismo ocidental estava diante da problemática da relação estrutura e sujeito, ou seja, a problemática da práxis histórica. O filósofo marxista húngaro não utilizou o conceito de experiência. Entretanto, percebe-se que sua preocupação filosófica fundamental, tal como a de Thompson, foi resgatar o sujeito histórico e a própria razão histórica, materialista e dialética, diante da ofensiva ideológica das posições irracionalistas e neopositivistas.

Como salientamos acima, na década de 1960, o marxismo hegemônico no Ocidente adotou a feição estruturalista, deslocando, por exemplo, as preocupações dialéticas de J. P. Sartre, L. Goldmann, H. Lefebvre, por um lado, e de G. Lukács e E. P. Thompson por outro. A miséria do estruturalismo - como nos diria Carlos Nelson Coutinho - exigiu o resgate da ontologia. Ela tornar-se-ia crucial nas décadas seguintes com a onda ideológica do pós-estruturalismo e do pósmodernismo (Anderson).

Primeiro, Lukács resgatou o sentido do conceito de ontologia. A perspectiva ontológica de Lukács é o oposto da ontologia clássica, metafísica, especulativa, não ancorada no real, no histórico, no material. Considerar o marxismo como uma ontologia significa reafirmar a "radicalidade" do método de Marx, no qual ser "radical" é ir até a raiz, isto é, ir até o homem, ou seja, o ser social naquilo que ele tem de "fundante" e de "estruturante": a práxis humana material e histórica. "O que aqui nos propomos - diz-nos Lukács no seu Esboço - é mostrar como o elemento filosoficamente resolutivo na ação de Marx consistiu em ter esboçado os lineamentos de uma ontologia histórico-materialista, superando teórica e praticamente o idealismo lógico-ontológico de Hegel”. 24

23 NICOLAZZI, Fernando. "A narrativa da experiência em Foucault e Thompson". Anos - UFRGS, Porto Alegre, v.11, n. 19/20, p. 35, 2004.

24 LUKÁCS, Georg. "As Bases da Atividade e do pensamento do Homem" In: O jovem Marx e outros escritos de filosofia. Rio de Janeiro: Editora UFRJ, 2007, p. 230. 
O ato materialista de "repor sobre os próprios pés" a ontologia de Hegel significa:

1) No plano epistemológico, a ontologia marxiana afasta todo elemento lógicodedutivo. Se os velhos materialistas tinham como ponto de partida o átomo; e se Hegel tinha como ponto de partida o ser abstrato (o "Espírito"), em Marx não existe nada análogo. É o que diz Lukács: "Todo existente deve ser sempre objetivo, ou seja, deve ser sempre parte (movente e movido) de um complexo concreto."

Assim, para Lukács, não existe algo por meio do qual se deduza logicamente a Realidade, algo como, por exemplo, o "Espírito" em Hegel mediante o qual se deduzia as objetivações mais complexas da cultura humana. O ser em seu conjunto, na ontologia marxiana, é visto como um processo histórico e as categorias são formas moventes e movidas dá própria matéria ("formas do existir, determinações da existência" - Marx).

Aqui entra a relação entre consciência e matéria. Na ontologia de Marx, não podemos subestimar a importância da consciência com relação ao ser material. Marx entendia a consciência como um produto tardio do desenvolvimento do ser material. Entretanto, o produto tardio não é jamais necessariamente um produto de menor valor ontológico, como afirma, por exemplo, a Ontologia de Hegel, numa inversão idealista, ao considerar as obras da cultura humana produto tardio da evolução do "Espírito", como um produto de menor valor ontológico. A consciência, como parte movente e movida do complexo concreto material, tem um real poder no plano do ser e não é carente de força, como supõem certos modos vulgares de interpretar Marx. Nesse momento, delineia-se a densa articulação dialética da experiência histórica proposta pelo materialismo histórico.

2) No plano histórico, a ontologia de Marx afasta todo elemento teleológico. As filosofias anteriores concebiam a posição teleológica como particularidade de um sujeito transcendente à Natureza e à Sociedade (as Ontologias religiosas); ou concebiam a posição teleológica como particularidade de uma natureza especial, na qual as correlações atuavam de modo teleológico, com a finalidade de atribuir à natureza e à sociedade tendências de desenvolvimento de tipo teleológico (as Ontologias imanentistas especulativas - Hegel).

$\mathrm{Na}$ Ontologia de Marx, a posição teleológica é uma particularidade do ser social. Entretanto, isso não significa que no plano da evolução histórica haja uma teleologia. É o que ressalta Lukács: "Numa sociedade tornada realmente social, a maior parte das atividades cujo conjunto põe a totalidade em movimento é certamente de origem teleológica, mas a sua existência real é feita de conexões causais que jamais e em nenhum sentido podem ser de caráter teleológico.”25

A geratriz básica do corpo de conceitos da abordagem lukacsiana do marxismo, a sua "Ontologia do Ser Social”, é a categoria de trabalho. Essa categoria fundamenta a Ontologia de Lukács como eminentemente histórico-materialista, pois é a partir do trabalho que iremos compreender toda a especificidade do ser social face aos outros modos de ser (o ser orgânico e o ser inorgânico). É a categoria trabalho que é a matriz ontológica da experiência histórica que Thompson buscou resgatar no sentido dialético, contrapondo-se às leituras estruturalistas, pós-estruturalistas e culturalistas.

Interessamo-nos em ver como Lukács, como filósofo radical, vai à raiz da experiência histórica, ao desvelar os nexos essenciais da categoria trabalho. A radi-

25 LUKÁCS, G. op. cit., 2007, p. 232. 
calidade ontológica de Lukács prepara-o para a crítica radical das posturas estruturalistas. Para Lukács, o trabalho é produto da evolução do ser orgânico, de uma forma mais simples de ser para uma forma mais complexa (a passagem de um tipo de ser a outro, por meio da qual ocorreu um "salto"). Essa forma mais complexa é algo qualitativamente novo, cuja gênese não pode jamais ser simplesmente "deduzida" da forma mais simples (esse "salto" é o que ocorreu na passagem do ser inorgânico para o ser orgânico, ou seja, a reprodução da vida em contraposição ao simples tornar-se outra coisa; e ocorreu na passagem do ser orgânico para o ser social, isto é, a adaptação ativa com a modificação consciente do ambiente, em contraposição à adaptação meramente passiva etc.) Diz Lukács: "Para que possa nascer o trabalho, enquanto base dinâmica estruturante de um novo tipo de ser, é indispensável um determinado grau de desenvolvimento do processo de reprodução orgânica". E continua adiante o nosso autor: "a essência do trabalho consiste praticamente em ir além dessa fixação dos seres vivos na competição biológica com seu mundo ambiente". ${ }^{26}$

Existem certos tipos de trabalho em algumas espécies de animais, inclusive com um certo desenvolvimento da divisão do trabalho (abelhas etc.). Entretanto, aí o trabalho não conseguiu se tornar princípio de desenvolvimento posterior, no sentido de um novo tipo de ser, no caso, o ser social, mantendo-se, ao contrário, como estágio estabilizado ("fixação dos seres vivos na competição biológica com seu mundo ambiente"), ou seja, como um "beco sem saída" no desenvolvimento biológico.

A essência do trabalho que instaurou esse "salto" em direção à constituição do ser social (o "trabalho humano") é efetivamente caracterizada por esse "ir além” da adaptação meramente passiva ao ambiente natural. Ir além dessa adaptação meramente passiva significa dar respostas aos carecimentos que o meio natural provoca no animal tornado homem.

O trabalho, a atividade laborativa que fabrica produtos, surge como solução de respostas aos carecimentos que a Natureza provoca. É o que Lukács nos diz: “O homem que trabalha é um ser que dá respostas". Todavia, para o filósofo húngaro, o homem torna-se um ser que dá respostas, isto é, um ser que fabrica produtos, na medida em que, paralelamente ao desenvolvimento social e em proporção crescente, ele generaliza, transformando em perguntas seus próprios carecimentos materiais e suas possibilidades de satisfazê-los por meio dos produtos sociais fabricados por ele.

Ora, o que Lukács quer ressaltar é que não apenas a resposta, mas também a pergunta é um produto imediato da consciência que guia a atividade laborativa. Todavia, isso não anula o fato de que o ato de responder é o elemento ontologicamente primário nesse complexo dinâmico. Ele destaca: "O momento essencialmente separatório (entre o ser da natureza orgânica e o ser social — G.A.) é constituído não pela fabricação de produtos, mas pelo papel da consciência [...] o produto, diz Marx, é um resultado que no início do processo existia 'já na representação do trabalhador', isto é, de modo ideal". ${ }^{27}$

Estaria Lukács defendendo princípios idealistas? É claro que não. O que ele quer enfatizar aqui - e isso é muito importante - é o perigo de desprezarmos esse campo de mediações que articulam a atividade laborativa, vendo apenas como relação imediata "trabalho = fabricação de produtos" e atribuindo à consciência um papel de mero epifenômeno da reprodução biológica.

26 LUKÁCS, G. op. cit., 2007, p. 236.

27 Ibidem. p. 237. 


\title{
Na raiz da experiência histórica
}

Para Lukács, o trabalho, que não é meramente a fabricação de produtos, abre a possibilidade do desenvolvimento superior dos homens que trabalham com a consciência, tendo, no início e dentro do processo de trabalho, um papel ativo e decisivo. É no trabalho, no complexo laborativo, que reside intimamente o complexo problemático mais alto: a relação dialética teleologia (consciência) e causalidade (natureza).

Outra coisa: além do trabalho expressar a nova peculiaridade do ser social, ele converteu-se no modelo da nova forma do ser em seu conjunto. Assim, o trabaIho é o modelo objetivamente ontológico de toda práxis social e toda práxis social contém em si esse caráter contraditório. Na verdade, eis o cerne da aproximação da ontologia do ser social de Lukács e da categoria de experiência de E. P. Thompson. A contradição entre experiência I e experiência II desvelada por Thompson é efetivamente o modo de operar da práxis social, cujo modelo objetivamente ontológico é o trabalho.

Diz-nos Lukács: "O trabalho é formado por posições teleológicas que, em cada oportunidade, põem em funcionamento séries causais". ${ }^{28}$ Temos presente aqui o complexo problemático mais alto que emerge da categoria trabalho: o da liberdade e o da necessidade; o da teleologia e o da causalidade. Esse complexo problemático será a base ontológica da categoria experiência de Thompson.

De um lado, nós temos a "liberdade": toda práxis é uma decisão entre alternativas, já que todo indivíduo singular, sempre que fez algo, deve decidir se o faz ou não. Assim, todo ato social, portanto, surge de uma decisão entre alternativas acerca de posições teleológicas futuras.

Mas, por outro lado, existe a "necessidade social", que exerce pressão sobre os indivíduos, frequentemente de maneira anônima, a fim de que as decisões deles tenham uma determinada orientação (a ideia de pressão indicada por Lukács aproxima-se da ideia da experiência vivida, a experiência que entra sem bater, verdadeira necessidade social). Marx delineia corretamente essa condição, dizendo que os homens são impelidos pelas circunstâncias a agir de determinado modo "sob pena de se arruinarem". Eles devem, em última instância, realizar por si as próprias ações, ainda que frequentemente atuem contra sua própria convicção.

Lukács expressou brilhantemente essa contraditoriedade do ser social, cuja condição é o complexo do trabalho, com as seguintes palavras:

\begin{abstract}
"Os homens fazem sua história — diz Marx — mas não em circunstâncias por eles escolhidas". Isso quer dizer o mesmo que antes formulamos do seguinte modo: o homem é um ser que dá respostas. Expressa-se aqui a unidade, contida de modo contraditoriamente indissolúvel no ser social, entre liberdade e necessidade; ela já opera no trabalho como unidade indissoluvelmente contraditória das decisões teleológicas entre alternativas com as premissas e conseqüências ineliminavelmente vinculadas por uma relação casual necessária. Uma unidade que se reproduz continuamente sob formas sempre novas, cada vez mais complexas e mediatizadas, em todos os níveis sócio-pessoais da atividade humana. ${ }^{29}$
\end{abstract}

A ontologia do ser social de Lukács perscruta as contradições candentes da experiência histórica — não teorizadas por Thompson — quando observa que, no

28 LUKÁCS, G. op. cit., 2007, p. 236.

29 Ibidem, p. 236. 
processo global do trabalho, ou no desenvolvimento da experiência histórica, o sujeito individual realiza, certamente, a posição teleológica de modo consciente, isto é, ele sabe o que está fazendo, mas sem jamais estar em condições de ver todos os condicionamentos da própria atividade, para não falarmos de todas as suas consequências, isto é, ele não sabe o que vai provocar. ${ }^{30}$

Muitas vezes o homem tem clara consciência de não poder conhecer senão uma pequena parte das circunstâncias em que vai atuar. Entretanto, sob pena de se arruinar, é absolutamente necessário que o homem aja. Essa situação ineliminável criada pela dialética do trabalho com posições teleológicas que põem em movimento séries causais desconhecidas pelo homem possui duas importantes consequências:

1. O aperfeiçoamento constante do trabalho com o "recuo das barreiras naturais" (Marx), isto é, o trabalho se diversifica nos mais diversos campos da atividade humana, subindo de nível tanto em extensão quanto em intensidade, fazendo com que cresça a faixa de determinações da realidade que se tornam cognoscíveis ao homem.

2. Esse processo de aperfeiçoamento do trabalho humano não pode eliminar a incognoscibilidade do conjunto das circunstâncias em que age o sujeito individual. Esse modo de ser do trabalho, a presença sempre de uma faixa do "desconhecido" desperta, também, "a sensação íntima de uma realidade transcendente". Segundo Lukács, essa é uma das fontes das formas ideológicas da magia e da religião, inclusive com o "modelo" direto do trabalho, sendo utilizado, como exemplo, para os mitos religiosos de criação divina da realidade, em que todas as coisas aparecem como produzidas teleologicamente por um criador consciente. Assim, o aperfeiçoamento do trabalho, uma das suas características ontológicas, chama à vida produtos sociais de ordem mais elevada.

A diferenciação interna do aperfeiçoamento do trabalho provoca a crescente autonomização das atividades preparatórias da práxis humana: surgem a matemática, a geometria, a física, a química etc., que eram originariamente momentos orgânicos do processo preparatório do trabalho. ${ }^{31}$ É a divisão do trabalho como

30 ALVES, Giovanni. Lukács e o século XXI: Trabalho, Estranhamento e Capitalismo Manipulatório. Bauru: Editora Práxis, 2010.

31 A perspectiva ontológica da dialética do trabalho exposta pelo último Lukács é a resposta materialista à problemática "autonomização dos conteúdos", tratada por Georg Simmel (1858-1918) de acordo com a perspectiva idealista da "filosofia da vida". Diz Simmel: "Com base nas condições e necessidades práticas, nossa inteligência, vontade, criatividade e os movimentos afetivos, elaboramos o material que tomamos do mundo. De acordo com nossos propósitos, damos a esses materiais determinadas formas, e apenas com tais formas esse material é usado como elemento de nossas vidas. Mas essas forças e esses interesses se libertam, de um modo peculiar, do serviço à vida que os havia gerado e aos quais estavam originalmente presos. Tornam-se autônomos, no sentido de que não se podem mais separar do objeto que formaram exclusivamente para seu próprio funcionamento e realização. Por exemplo, todo conhecimento parece ter um sentido na luta pela existência. Saber o verdadeiro comportamento das coisas tem uma utilidade inestimável para a preservação e o aprimoramento da vida. Mas o conhecimento não é mais usado a serviço dos propósitos práticos: a ciência tornou-se um valor em si mesma. Ela escolhe seus objetos por si mesma, modela-os com base em suas necessidades internas, e nada questiona para além de sua própria realização." (SIMMEL, 2006) Essa dialética entre formas e conteúdo ou a guinada da determinação das formas pelas matérias da vida para a determinação de suas matérias pelas formas que se tornaram valores definitivos é o modo de Simmel conceber a "alienação". Entretanto, como falta-lhe uma ontologia histórico-materialista do ser social, a ideia de que "os meios tornam-se fins em si mesmos", ou ainda, "as formas criadas pelas finalidades e pelas matérias da vida se desprendem dela e se tornam finalidade e matéria de sua própria existência", aparece para ele meramente como o "destino" irremediável da dialética da vida, em vez de ser percebida como produto da dialética histórico-materialista do trabalho. O sociólogo Georg Simmel foi o mais importante e mais influente filósofo do círculo de Max Weber, frequentado por Lukács em sua juventude. Segundo Lukács (em 1953), o pensamento de Simmel deve ser compreendido como expressão do descontentamento anticapitalista dos intelectuais alemães, e situado no quadro global da tendência de crítica anticapitalista da cultura. 
consequência do desenvolvimento do próprio trabalho que cria tipos de posições teleológicas novas que, com o nascimento das classes sociais com interesses antagônicos, se tornam a base espiritual-estruturante do complexo laborativo (aquilo que o marxismo chamaria de ideologia).

Georg Lukács, desenvolvendo a sua Ontologia do Ser Social a partir do "trabalho com posições teleológicas que movimenta séries causais", realça uma das características da Ontologia de Marx: a negação de uma teleologia na História. Diz ele: "O processo global da sociedade é um processo causal, que possui suas próprias normatividades, mas não é jamais objetivamente dirigido para a realização de finalidades. Mesmo quando alguns homens ou grupos de homens conseguem realizar suas finalidades, os resultados produzem, via de regra, algo que é inteiramente diverso daquilo que se havia pretendido."

Portanto, o processo do trabalho, que contém, no seu íntimo, a dialética entre liberdade e necessidade, teleologia e causalidade, possui também como uma de suas características ontológicas (1) o aperfeiçoamento do próprio trabalho que expõe aos homens a realidade de uma dialética cumulativa entre o "conhecido" e o "desconhecido", em que, no nível da história, (2) o homem está cada vez mais à mercê do "desconhecido" casual.

Por exemplo, certos eventos econômicos podem surgir à mente, com a aparência de irresistíveis catástrofes naturais, como foi a crise de 1929; e isso apesar de os homens terem consciência de que são capazes de assumir posições teleológicas no processo do trabalho cotidiano. Entretanto, Lukács ressalta que "o fator subjetivo conserva-se sempre, em muitos campos, como um fator por vezes modificador e, por vezes, até mesmo decisivo".

Essa é a contraditoriedade concreta que uma ontologia materialista tornada histórica afirma ao descobrir a gênese, o crescimento, as contradições no interior do desenvolvimento unitário do ser social instituído pelo complexo do trabalho.

\section{Experiência histórica, produção social e totalidade concreta}

Podemos dizer que o conceito de produção, base do materialismo histórico a partir do qual se explica a superestrutura, possui como síntese concreta o conceito de experiência ou ainda o conceito de práxis social, que tem como fundamento a categoria trabalho. Desse modo, as relações sociais de produção, base da matéria social, têm como nexo crucial a dialética própria da categoria trabalho. A superestrutura é explicada a partir da práxis social ou da matéria histórica, na medida em que a determina e é determinada por ela. Essa "determinação determinada” (Mészáros) inscrita na posição teleológica como trabalho social (Lukács) é o próprio cerne essencial da experiência histórica (Thompson).

Na Introdução dos Grundrisse (1857), Karl Marx tratou do conceito de produção em geral na perspectiva da produção como totalidade concreta. Nesse ensaio metodológico, Marx utiliza a sintaxe dialético-hegeliana para apreender o sentido concreto da categoria de produção, base do materialismo histórico. Produção, consumo, distribuição, troca (circulação), momentos compositivos da produção em geral. Marx discorre sobre a categoria de produção, buscando tratar depois da relação geral entre produção, distribuição, troca e consumo. Diz ele: "A produção é imediatamente consumo." E logo a seguir: "O consumo é imediatamente produção." 
Utilizando a sintaxe dialética, Marx salienta que cada um é imediatamente seu contrário. Mais adiante, observa: "O resultado a que chegamos não é que produção, distribuição, troca e consumo são idênticos, mas que todos eles são membros de uma totalidade, diferenças dentro de uma unidade." E conclui: "Uma produção determinada, portanto, determina um consumo, uma troca e uma distribuição determinados, bem como relações determinadas desses diferentes momentos entre si. A produção, por sua vez, certamente é também determinada, em sua forma unilateral, pelos outros momentos." 32

Enfim, as observações de Marx possuem um caráter metodológico crucial que ilumina o tratamento teórico da relação entre base e superestrutura ou, ainda, a relação entre estrutura e sujeito. Existe uma dialética entre os momentos constitutivos da produção, sendo ela uma determinação reflexa; ou, ainda, a experiência da produção implica a produção da experiência como trabalho/posição teleológica (os momentos da ideologia, política e relações jurídicas).

Em “História e Consciência de Classe” (1923), Lukács salientou que é a categoria totalidade que distingue o marxismo das ciências burguesas e não o predomínio da economia, a base, sobre as instâncias ideológicas, políticas e jurídicas. Essa é a resolução dialética da problemática base-superestrutura feita pelo marxismo humanista que coloca o homem - sujeito histórico - no centro da atividade social (por exemplo, no capítulo intitulado "O fenômeno da reificação", Lukács colocou como epígrafe a frase de Marx: "Ser radical é tomar as coisas pela raiz. Mas, para o homem, a raiz é o próprio homem"). ${ }^{33}$ Mesmo não conhecendo ainda os Grundrisse, Lukács (em “História e Consciência de Classe”) resgatou a centralidade metodológica da categoria de totalidade concreta na perspectiva do materialismo histórico. Mais tarde, Lukács apreenderia a base ontológica da categoria de totalidade concreta por meio da categoria de trabalho como posição teleológica. ${ }^{34}$

Outro marxista humanista, Antônio Gramsci expressou a mesma resolução dialética da relação entre estrutura e sujeito, e base e superestrutura, destacando o conceito de "bloco histórico" como totalidade concreta. Tal como Lukács e Thompson, Antonio Gramsci deparou-se com a questão teórica central do marxismo: a relação entre estrutura e superestrutura, entre teoria e prática, entre forças materiais e ideologia. Primeiro, Gramsci rejeita toda visão determinista e mecanicista dessa relação. Não existe uma estrutura que mova de modo unilateral o mundo superestrutural das ideias; não há uma simples conexão de causa e efeito, mas um conjunto de relações e reações recíprocas, que devem ser estudadas em seu concreto desenvolvimento histórico. O marxismo de Gramsci possui também uma base ontológica. ${ }^{35}$ É fundamental quanto a isso a pesquisa empreendida nos "Cadernos do Cárcere", no qual Gramsci tende a considerar abstrata a distinção entre estrutura (as relações sociais de produção) e superestrutura (as ideias, os costumes, os comportamentos morais, a vontade humana). Na concretude histórica, há convergência entre os dois níveis, uma convergência que conhece a distinção e a dialética, mas que se resolve numa "unidade real". Diz ele:

A pretensão (apresentada como postulado essencial do materialismo histórico) de apresentar e expor toda flutuação da política e da ideologia

32 MARX, Karl. Grundrisse: Manuscritos Econômicos (1857-1858)/esboços da Crítica da Economia Política. Tradução: Mário Duayer e Nélio Schneider. São Paulo: Boitempo Editorial, p. 47.

33 LUKÁCS, Georg. História e Consciência de Classe: Estudos sobre a Dialética Marxista. Tradução: Rodnei Nascimento. São Paulo: Martins Fontes, 2003, p. 193.

34 LUKÁCS, Georg. Para Uma Ontologia do Ser Social. v.Il. Tradução: Mário Duayer e Nélio Schneider. São Paulo: Boitempo Editorial, 2013.

35 COUTINHO, Carlos Nelson. Gramsci - Fontes do pensamento Político. Porto Alegre: L\&PM, 1981. 
como uma expressão imediata da estrutura deve ser combatida, no plano teórico, como um infantilismo primitivo, ou, no plano prático, valendo-se do testemunho autêntico de Marx, escritor de obras políticas e históricas concretas. ${ }^{36}$

Para Gramsci, existe uma dificuldade para identificar estaticamente, em cada momento concreto, a estrutura. Na realidade, a estrutura entendida em si, separadamente do processo histórico, não existe: e, ainda que ela seja objetivamente identificável, trata-se de um movimento no interior da história, não de uma realidade externa à história e situada abaixo dela. Por isso, a política deve levar em conta as tendências de desenvolvimento da estrutura, mas isso não significa que todas elas devam necessariamente se realizar. ${ }^{37}$ Disso decorre a possibilidade do erro político, que o materialismo histórico mecânico não admite, considerando que todo ato político é rigidamente determinado pela estrutura. Trata-se, ao contrário, de captar um movimento e suas contradições; ou nos termos da ontologia do complexo do trabalho, exposta por Lukács, captar o trabalho com posições teleológicas que põem em movimento séries causais desconhecidas. Explicita-se, assim, a base ontológica do pensamento de Antonio Gramsci, tanto quanto o de E. P. Thompson.

Desse modo, práxis social e experiência histórica da classe, que pressuporiam a dialética entre liberdade/necessidade, causalidade/teleologia, estariam no centro constitutivo da categoria de "bloco histórico" de Antonio Gramsci. Por isso a importância dos "intelectuais orgânicos", agentes que fariam a síntese concreta entre base e superestrutura no interior do bloco histórico. Mais uma vez o conceito de experiência como práxis social constitutiva da própria classe social ocorreria indissociável da ação de intelectuais como organizadores da cultura.

Na verdade, a categoria de experiência em Thompson carrega em si e para si a dialética da práxis social e da processualidade histórica. Por exemplo, experiência vivida e experiência percebida são dimensões indissociáveis da experiência histórica no plano da práxis social. Vivido e percebido constituem o fazer-se do em-si e para-si da classe. Na medida em que E. P. Thompson dialoga com o último Lukács - o Lukács da Ontologia do Ser Social — resgatamos a densidade ontológica do conceito de experiência em Thompson. Experiência vivida, experiência percebida, experiência histórica de classe, o fazer-se da classe ganharia um estatuto ontológico que daria consistência teórico-crítica ao conceito, evitando os usos pós-modernistas do conceito que reduziria a coerência a práticas culturais dissociadas da apreensão da totalidade concreta da produção do capital. O resgate da experiência histórica do sujeito pessoal de classe é importante nos dias de hoje, em que se coloca como tarefa fundamental o renascimento do marxismo.

Recebido em 15/09/2013

Aprovado em 15/11/2013

36 GRAMSCI, Antonio. Cadernos do Cárcere apud ZANGHERI, Renato. Bloco Histórico. Disponível em: http:// www.acessa.com/gramsci/?id=632\&page=visualizar. Acesso em: 14 de setembro de 2013.

37 ZANGHERI, Renato. Bloco Histórico. Disponível em: http://www.acessa.com/gramsci/?id=632\&page=visualizar. Acesso em: 14 de setembro de 2013. 